\title{
FORWARD CHAINING UNTUK MENDETEKSI KERUSAKAN KOMPUTER DAN LAPTOP BERBASIS ANDROID
}

\author{
${ }^{1}$ Muh.Rasyid Ridha, ${ }^{2}$ Wahyuddin \\ 1,2 Program Studi Sistem Informasi, Fakultas Teknik dan Ilmu Komputer \\ Universitas Islam Indragiri (UNISI) \\ Jl. Provinsi No. 01 Tembilahan Hulu, Indragiri Hilir, Riau - Indonesia \\ Email: rasyid4sky@gmail.com, yudi.p.b.ym@gmail.com
}

\begin{abstract}
ABSTRAK
Saat ini teknisi komputer membutuhkan waktu lama dalam mendiagnosa kerusakan yang terjadi pada sebuah komputer, bahkan sering kali teknisi menunda pekerjaannya hanya untuk menghasilkan solusi dari kerusakan komputer. Perkembangan sistem pakar dapat digunakan untuk memberikan solusi secara cepat dan tepat, misalnya dalam hal menentukan jenis kerusakan pada komputer. Solusi dari permasalahan tersebut adalah dengan merancang perangkat lunak menggunakan metode forward chaining dimana metode forward chaining sebagai proses pelacakan. Metode ini cocok digunakan untuk sistem pakar yang mendiagnosis sesuatu yang belum pasti dengan melakukan perhitungan secara akurat untuk menentukan nilai keyakinannya. Dengan pengujian sistemyang menggunakan metode Black-box yang diperoleh dari sistem pakar berbasis android ini mampu melakukan diagnosis dengan cepat, tepat dan akurat terhadap gejala kerusakan yang terjadi. Dengan kelayakan sistem yang mampu membantu teknisi dalam memberikan solusi dan penanganan secara tepat dari kerusakan yang terjadi pada komputer.
\end{abstract}

Kata Kunci: Forward Chaining, Komputer/Laptop, Android

\section{PENDAHULUAN}

Teknologi informasi merupakan salah satu teknologi yang sedang berkembang pesat pada saat ini.seorang teknisi komputer membutuhkan waktu lama dalam mendiagnosa kerusakan yang terjadi pada sebuah komputer, bahkan sering kali teknisi menung pekerjaannya hanya untuk menghasilkan solusi dari kerusakan komputer, seperti kejadian yang saya alami saat terjadi kerusakan pada keyboard komputer yang saya miliki, saya masih harus menunggu beberapa hari untuk mengetahui jenis kerusakan yang terjadi. Begitu juga dengan hasil wawancara dengan teknisi dari beberapa toko komputer dengan rata-rata waktu 15 sampai 20 menit untuk menentukan jenis kerusakan yang terjadi dan itupun belum pasti kerusakannya. Bahkan terkadang teknisi belum pernah mengalami masalah yang sama, sehingga dibutuhkan waktu yang lebih lama untuk menentukan jenis kerusakan dan sekaligus penyelesaiannya.

Dengan adanya perkembangan teknologi informasi,Khususnya di bidang ilmu pengetahuan dan teknologi telah memudahkan manusia dalam melakukan kegiatan sehari-hari, hal ini dapat di rasakan dengan hadir nya computer yang mampu mengelola dan mempermudah pekerjan manusia lebih mudah dan akurat.

Sistem pakar dikembangkan sejalan dengan adanya teknologi informasi. Pembangunan sistem pakar bertujuan sebagai sarana bantu untuk memberikan solusi di dalam kehidupan kita. Salah satu contohnya adalah kasus kerusakan komputer merupakan kasus yang memerlukan bantuan seorang pakar (teknisi) dalam menyelesaikan masalah dengan mengandalkan pengetahuan yang dimilikinya. Saat ini teknisi membutuhkan waktu yang cukup lama untuk mendiagnosa kerusakan komputer, bahkan teknisi sering sekali menunda perkerjannya hanya untuk menghasilkan solusi dari kerusakan komputer. Pada tugas akhir ini dibuat perangkat lunak untuk mengatasi kasus kerusakan komputer, dimana bisa membantu para teknisi untuk mendiagnosa kerusakan komputer dengan menghemat waktu. Di aplikasi ini dapat membantu teknisi senior untuk mendapatkan solusi dengan cepat dan teknisi junior apabila ada jenis dan ciriciri yang di temukan lagi bisa menambahkannya di basis aturan. Perangkat lunak yang dimaksud 
adalah sistem pakar untuk diagnosis kerusakan komputer yang di desain untuk memodelkan/mengemulasi kemampuan seorang pakar dalam memecahkan suatu masalah yang berbasiskan pada pengetahuan pakar itu sendiri. Bahasa pemrograman yang digunakan sebagai pembangun sistem adalah Android dan firebase untuk pengolahan database- nya [1].

\section{LANDASAN TEORI}

System Development Life Cycle (SDLC) menurut Azhar Susanto [2] dapat disimpulkan sebagai salah satu metode pengembangan sistem informasi yang popular pada saat sistem informasi pertama kali dikembangkan. Metode SDLC adalah tahapan-tahapan pengembangan sistem informasi yang pertama kali dikembangkan yang dilakukan oleh analisis sistem dan programmer untuk membangun sebuah sistem informasi.

Konsep dasar sistem pakar mencakup beberapa persoalan mendasar, antara lain apa yang dimaksud dengan keahlian, siapa yang disebut pakar, bagaimana keahlian dapat ditransfer, dan bagaimana sistem bekerja. Keahlian sering dicapai dari pelatiahan, membaca, dan mempraktekkan [3].

Keahlian adalah pengetahuan ekstensif yang spesifik terhadap tugas yang dimiliki pakar. Berikut adalah daftar kemungkinan tipe pengetahuan:

1. Teori tentang domain persoalan.

2. Aturan dan prosedur yang berkaitan dengan domain persoalan umum.

3. Aturan (heuristik) tentang apa yang harus dilakukan dalam situasi persoalan tertentu.

4. Strategi global untuk memecahkan tipe persoalan ini.

5. Matapengetahuan (pengetahuan tentang pengetahuan).

6. Fakta tentang area persoalan.

Pakar yang memiliki tipe pengetahuan tersebut mampu membuat keputusan yang lebih baik dan lebih cepat dibanding non-pakar dalam memecahkan persoalan komplek.Sistem pakar tidak terlepas dari elemen manusia yang terkait didalamnya. Personil yang terkait pada sistim pakar ada 4, yaitu pakar (expert), pembangun pengetahuan (knowledge engineer), pembangun sistem (system engineer), pemakai (user).

Melalui pemodelan sistem, dapat digambarkan aliran data yang akan diproses menjadi informasi dan aliran distribusinya secara sederhana, sehingga arus data dan informasi dapat terlihat secara jelas. Ada tiga alasan yang menyebabkan pemakaian pemodelan sistem, yaitu [4]:

1. Dapat memfokuskan perhatian pada hal-hal penting dalam sistem tanpa mesti terlibat terlalu jauh.

2. Mendiskusikan perubahan dan koneksi terhadap kebutuhan pemakai dengan resiko dan biaya minimal.

Java adalah salah satu bahasa pemrograman tertua, dimulai dari era 1990-an sampai sekarang, bahasa pemrograman ini masih populer dan penggunaan terbesarnya adalah dalam pembuatan aplikasi native untuk android. Bahasa pemrograman yang terlahir dari The Green Project ini termasuk bahasa tingkat tinggi [5].

Untuk mengembangkan aplikasi berbasis Java diperlukan Java Development Kit (JDK). JDK ini dapat didapatkan secara bebas yang sudah di unggah di web Sun Microsystem. Syntax yang ada dalam bahasa pemrograman Java sama dengan syntax pada $C_{++}$dan sistematikanya sama dengan sistematika pada SmallTalk. Java dengan menggunakan bahasa pemrograman ini juga lebih mudah dan sangat membantu sekali terutama dalam mengembangkan software dalam skala besar, multiplatform, multi interfacememiliki fitur garbage collection, multithreading dan tingat keamanan yang lebih baik. Java tidak hanya powerfull, pengembangan software.

Android adalah sebuah sistem operasi yang berbasis Linux untuk telepon seluler seperti smartphone dan tablet android, android wear, dan android tv. Android menyediakan platform terbuka bagi para pengembang untuk menciptakan aplikasi mereka sendiri untuk digunakan oleh bermacam peranti bergerak. Awalnya, Google Inc., pendatang baru yang membuat peranti lunak untuk ponsel. Kemudian untuk mengembangkan android, dibentuklah Open Handset Alliance, 
konsorium dari 34 perusahaan peranti keras, peranti lunak, dan telekomunikasi, termasuk Google, HTC, Intel, Motorola, Qualcomm, T-Mobile, dan NVIDIA [6].

Firebase memiliki produk utama, yaitu menyediakan database realtime dan backend sebagai layanan (Backend as a Service). Layanan ini menyediakan pengembang aplikasi API yang memungkinkan aplikasi data yang akan disinkronisasi di klien dan disimpan di cloud Firebase ini. Firebase menyediakan library untuk berbagai client platform yang memungkinkan integrasi dengan Android, iOS, JavaScript, Java, Objective-C dan Node aplikasi Js dan dapat juga disebut sebagai layanan DbaaS (Database as a Service) dengan konsep realtime. Firebase digunakan untuk mempermudah dalam penambahan fitur-fitur yang akan dibangun oleh developer [7]. Untuk melihat ilustrasi arsitektur sistem database dapat dilihat pada Gambar 2.5 di bawah ini :

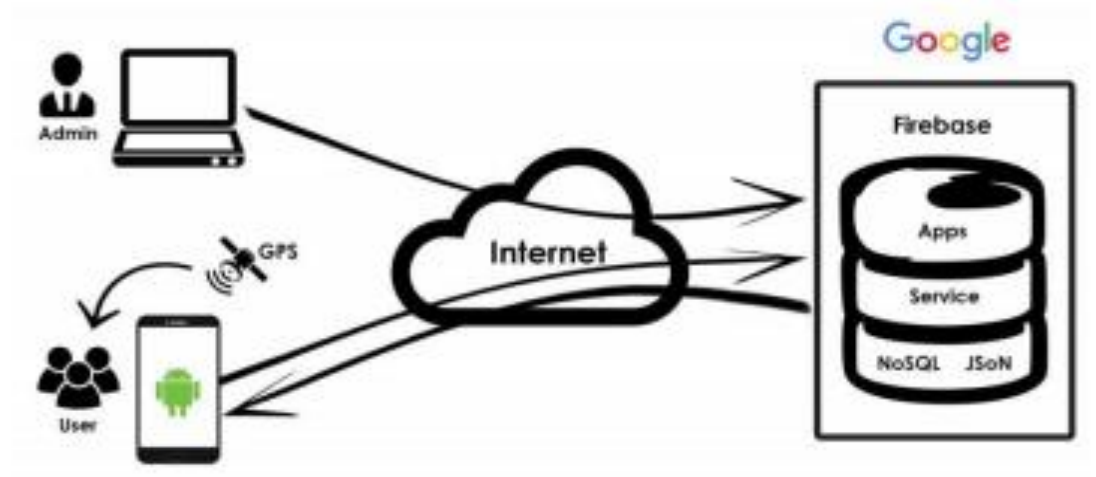

\section{Gambar 1. Arsitektur Sistem Firebase}

$\mathrm{XML}$ adalah sebuah standar yang digunakan untuk menstrukturkan informasi dalam sebuah dokumen menjadi sejumlah bagian dan untuk mengidentifikasi bagian tersebut. Dokumen bukan hanya berupa dokumen teks, tetapi termasuk juga data gambar, persamaan matematika, rumus bangun kimia, dan berbagai jenis informasi yang dapat distrukturkan [8].

Android Studio merupakan sebuah Integrated Development Environment (IDE) khusus untuk membangun aplikasi yang berjalan pada platform android. Dikutip dari situs resminya https://developer.android.com/, Android Studio adalah Lingkungan Pengembangan Terpadu Integrated Development Environment (IDE) untuk pengembangan aplikasi Android, berdasarkan IntelliJ IDEA . Selain merupakan editor kode IntelliJ dan alat pengembang yang berdaya guna, Android Studio menawarkan fitur lebih banyak untuk meningkatkan produktivitas Anda saat membuat aplikasi Android. Untuk dapat digunakan dalam pembuatan aplikasi android maka android studio membutuhkan plug-in yang disebut ADT, ADT adalah kepanjangan dari android development tools yang menjadi penghubung antara IDE android studio dengan Android Software Development Kit [9].

Sebuah perangkat lunak perlu dijaga kualitasnya bahwa kualitas bergantung kepada kepuasan pelangan (Customer). Sering perangkat lunak megandung kesalahan (error) pada peroses-proses tertentu perangkat lunak sudah berada di tangan user. Kesalahan-kesalah (error) pada peragkat lunak ini sering disebut dengan "Bug". Untuk menghindari banyaknya buk maka di perlukan adanya pengujiann perangkat lunak sebelum perangkat lunak diberikan ke pelangan atau selama perangkat lunak masih terus di kembangkan [10].

\section{METODE PENELITIAN}

Metode penelitian merupakan gambaran pendekatan, tipe, jenis, dan desain penelitian. Flowchart penelitian Sistem Pakar Diagnosa Kerusakan Komputer/Laptop dapat dilihat pada gambar 


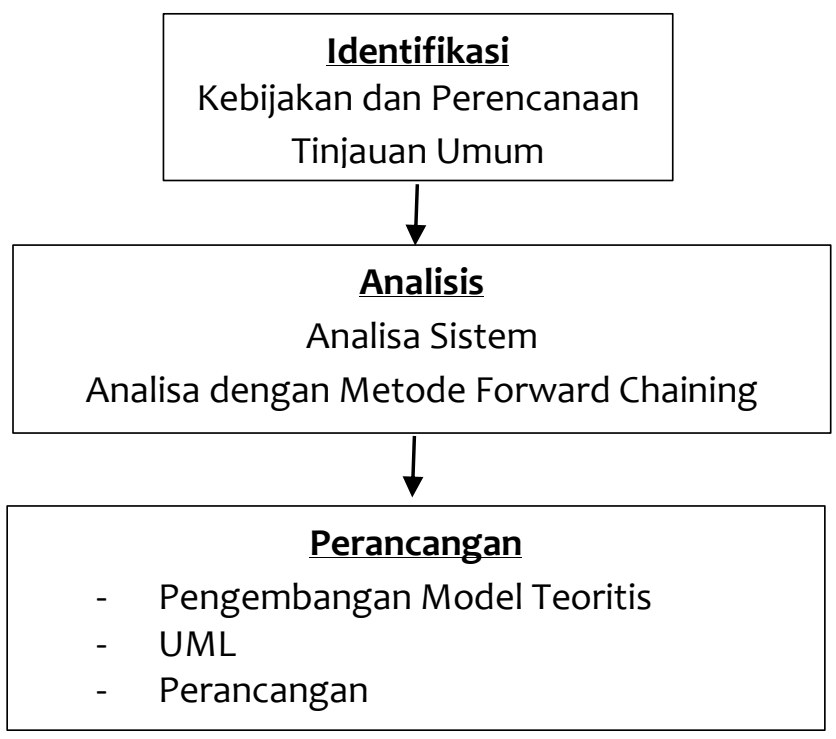

Gambar 2. Metode Penelitian

\subsection{Kebijakan dan Perencanaan}

Kebijakan dan perencanaan ini dimaksudkan untuk menjabarkan apa saja tahapan serta kebutuhan yang dilakukan dalam tahap perencanaan untuk menentukan langkah selanjutnya [12].

\subsection{Analisis Masalah}

Dalam Perbaikan komputer/Laptop tidak terlepas dari gangguan kerusakan, penelitian ini dilakukan untuk membangun aplikasi sistem pakar penelusuran Kerusakan komputer/laptop dengan menggunakan metode forward chaining. Pada metode ini dimana setiap gejala-gejala Kerusakan yang nampak dapat di telusuri jenis Kerusakan, dan pengendalianya [13].

Tabel 1. Basis Pengetahuan Kerusakan Hardware Komputer/Laptop

\begin{tabular}{|c|c|c|c|}
\hline Kode & Gejala-Gejala & Kode & Kerusakaan \\
\hline G1 & Motherbord Rusak & PS1 & PC Over Head \\
\hline $\mathrm{G}_{2}$ & Power Supply Rusak & & \\
\hline G3 & Memori Kotor & & \\
\hline G4 & Memori Tidak Terdeteksi & & \\
\hline G5 & Tidak Ada Aliran Listrik & PS2 & PC Mati \\
\hline G6 & Tegangan Listrik Tidak Stabil & & \\
\hline G7 & PC Sering Mati Tiba-Tiba & & \\
\hline G8 & Suhu PC Panas & & \\
\hline G9 & Semua Peragkat Tidak Terdeteksi Oleh OS & MB1 & Motherboard \\
\hline G10 & Kipas Motherbord Tidak Berfugsi & & $\begin{array}{l}\text { Mengalami } \\
\text { Masalah }\end{array}$ \\
\hline G11 & Bunyi Beep 3 kali,Beep terus 3 kali berturut & MB2 & Kapasitor \\
\hline G12 & Bunyi Beep Panjang & & $\begin{array}{l}\text { Motherbord } \\
\text { Bermasalah }\end{array}$ \\
\hline G13 & HDD Tidak Terdeteksi Saat Operasi booting & HD1 & $\begin{array}{l}\text { IC BIOS } \\
\text { Bermasalah }\end{array}$ \\
\hline G14 & Koneksi Kabel HDD Tidak Benar & $\mathrm{HD} 2$ & Kabel Sata \\
\hline G15 & HDD tidak terdeteksi & & $\begin{array}{l}\text { Hardisk } \\
\text { Bermasalah }\end{array}$ \\
\hline
\end{tabular}

Ridha, Forward Chaining Untuk Mendeteksi Kerusakan Komputer Dan Laptop Berbasis Android 


\begin{tabular}{|c|c|c|c|}
\hline Kode & Gejala-Gejala & Kode & Kerusakaan \\
\hline G16 & Setting Jumper CD Drive Salah & HD3 & $\begin{array}{l}\text { Seting Jumper } \\
\text { Hardisk } \\
\text { Bermasalh }\end{array}$ \\
\hline G17 & $\begin{array}{l}\text { Booting Mengalami Kesalahan Invalid partition } \\
\text { Table, OS Tidak Bisa Di Aktifkan }\end{array}$ & HD4 & $\begin{array}{l}\text { Partition } \\
\text { Hardisk } \\
\text { Bermaslah }\end{array}$ \\
\hline G18 & CD/DVD Tidak Terdeteksi Saat Booting & DR1 & $\begin{array}{l}\text { Setup Bios } \\
\text { Bermasalh }\end{array}$ \\
\hline G19 & Driver CD/DVD Rusak & DR2 & $\begin{array}{l}\text { Driver CD/DVD } \\
\text { Bermasalah }\end{array}$ \\
\hline G20 & Layar Monitor Gelap dan Hitam & VG1 & $\begin{array}{l}\text { Monitor/LCD } \\
\text { Mengalami } \\
\text { Kerusakan }\end{array}$ \\
\hline G21 & Komputer Heng & VG2 & Gangguan \\
\hline G22 & OS Tidak Normal & & Pada VGA Card \\
\hline G23 & Ada titik Kecil Pada Layar Monitor & & \\
\hline G24 & USB Tidak Dapat Terdeteksi & US1 & USB Rusak \\
\hline G25 & USB Driver Tidak Berfugsi Dengan Baik & US2 & $\begin{array}{l}\text { Driver USB } \\
\text { mengalami } \\
\text { kerusakan }\end{array}$ \\
\hline G26 & $\begin{array}{l}\text { Komputer/Laptop mati Saat Update System } \\
\text { Bios }\end{array}$ & Bl1 & $\begin{array}{l}\text { Bios } \\
\text { mengalami } \\
\text { error }\end{array}$ \\
\hline
\end{tabular}

\subsection{Mesin Inferensi}

Mesin Inferensi merupakan proses untuk menghasilkan informasi dari fakta yang diketahui atau diasumsikan. Dalam penelitian ini metode inferensi yang digunakan adalah Forward Chaining. Adapun pohon keputusan dari metode inferensi yang digunakan dapat dilihat pada Gambar 3..

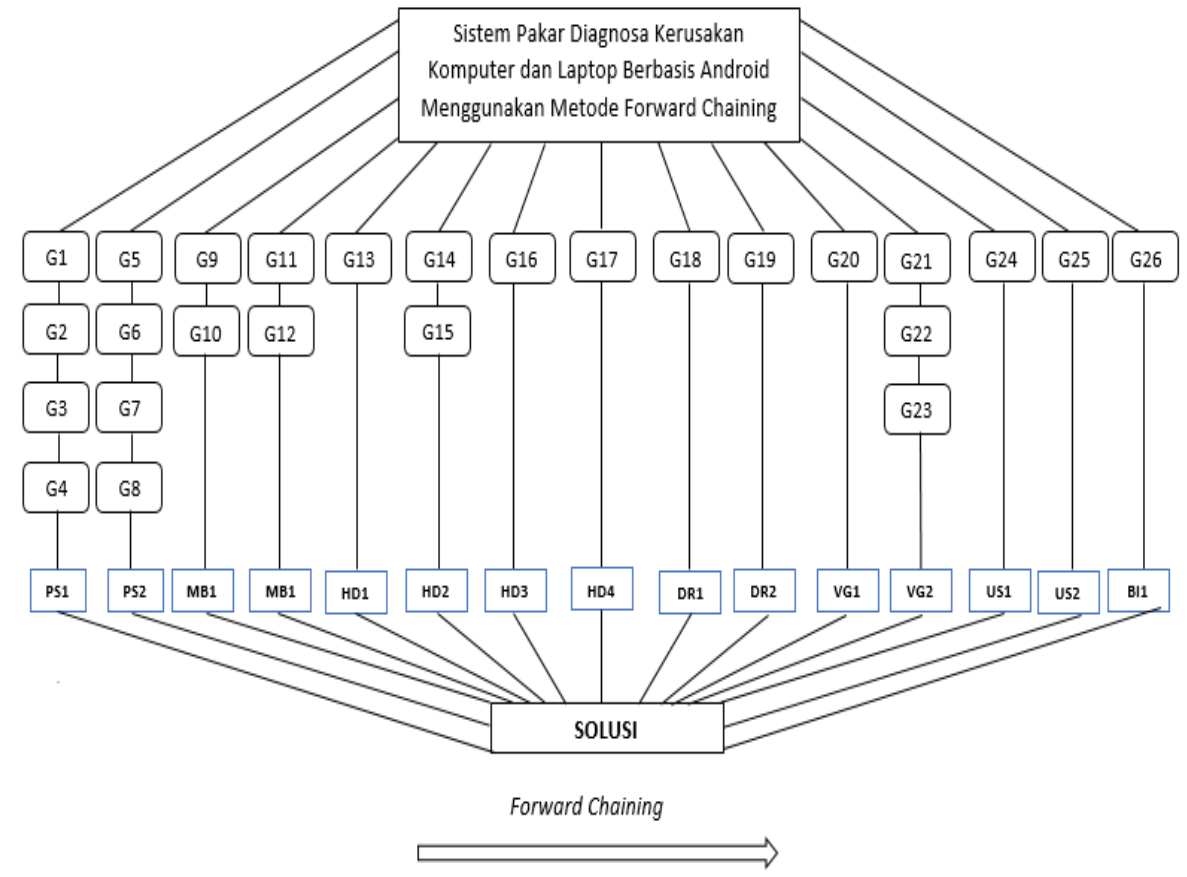

Gambar 3. Pohon Keputusan Forward Chaining

Ridha, Forward Chaining Untuk Mendeteksi Kerusakan Komputer Dan Laptop Berbasis Android 
Berdasarkan pohon keputusan yang telah di kemukakan pada Gambar 3, dapat ditunjukkan bahwa ada beberapa aturan-aturan yang digunakan dalam sistem pakar ini sebagai dapat dilihat pada tabel 3. berikut :

Tabel 2. Aturan (Rule) Forward Chaining

\begin{tabular}{ll}
\hline Id & \multicolumn{1}{c}{ Rule (IF THEN) } \\
\hline R1 & If $G 1$ and $G 2$ and $G 3$ and $G 4$ Then PS1 \\
R2 & If $G 5$ and $G 6$ and $G 7$ and $G 8$ Then PS2 \\
R3 & If $G 9$ and $G 10$ Then $M B 1$ \\
R4 & If $G 11$ and $G 12$ Then $M B 2$ \\
R5 & If $G 13$ Then HD1 \\
R6 & If $G 14$ and $G 15$ Then HD2 \\
R7 & If $G 16$ Then HD3 \\
R8 & If $G 17$ Then HD4 \\
R9 & If $G 18$ Then $D R 1$ \\
R10 & If $G 19$ Then DR2 \\
R11 & If $G 20$ Then VG1 \\
R12 & If $G 21$ and $G 22$ and $G 23$ Then VG2 \\
R13 & If $G 24$ Then US1 \\
R14 & If $G 25$ Then US2 \\
R15 & If $G 26$ Then Bl1 \\
\hline
\end{tabular}

Keterangan pada tabel 3. di atas, penjelasan gejala penyakit dan jenis penyakit yang terdapat pada rule-rule dapat dilihat pada tabel basis pengetahuan yang dikemukakan diatas, pengendaliannya dijelaskan sebagaimana berikut:

Tabel 3. Solusi

\begin{tabular}{|c|c|c|}
\hline Kode & $\begin{array}{c}\text { Jenis } \\
\text { Kerusakaan }\end{array}$ & Solusi Kerusakan \\
\hline S1 & PC Over Head & $\begin{array}{l}\text { Ganti motherbord dengan yang baru. } \\
\text { Lepas kabel yang terhubung dengan motherbord. } \\
\text { Cabut memori dan bersihkan memori degan kuas atau penghapus } \\
\text { pengsil lalu pasang degan slot yang lain. } \\
\text { Cek hardist padan run program pada system oprasi. }\end{array}$ \\
\hline S2 & PC Mati & $\begin{array}{l}\text { Cek kabel power supply atau satuan listrik apakah sudah terhubung } \\
\text { degan satuan listrik utama. } \\
\text { Gunakan Stabilizer atau UPS atau pindahkan ke stop kontak yang } \\
\text { lain tampa menggunakan terminal. } \\
\text { Cek kipas power supply apakan berguna dengan baik maka tidak } \\
\text { ganti dengan yang baru. } \\
\text { Cek tegaggan power supply apakah sudah sesuai dengan } \\
\text { kebutuhan motherbord. }\end{array}$ \\
\hline S3 & $\begin{array}{l}\text { Motherboard } \\
\text { Mengalami } \\
\text { Masalah }\end{array}$ & $\begin{array}{l}\text { Ganti motherbord dengan yang baru. } \\
\text { Cek kabel sokit kipas pada motherbord dan masukan kembalin PC. }\end{array}$ \\
\hline S4 & $\begin{array}{l}\text { Kapasitor } \\
\text { Motherbord } \\
\text { Bermasalah }\end{array}$ & $\begin{array}{l}\text { Cek momori pada motherbord jika kotor bersihkan lalu pasang } \\
\text { dengan benar. } \\
\text { Matikan PC lalu diamkan beberapa menit agar tidak merambat } \\
\text { pada kerusakan lain. }\end{array}$ \\
\hline
\end{tabular}




\begin{tabular}{|c|c|c|}
\hline Kode & $\begin{array}{c}\text { Jenis } \\
\text { Kerusakaan }\end{array}$ & Solusi Kerusakan \\
\hline S5 & $\begin{array}{l}\text { IC BIOS } \\
\text { Bermasalah }\end{array}$ & $\begin{array}{l}\text { Cek pada setup bios apakah masih bisa mendeteksi hardis pada } \\
\text { beberapa motherbord setup bios dapat di tampilkan dengan } \\
\text { menekan tombol f } 2 \text { atau del pada saat booting bios setelah bios } \\
\text { muncul pilih opsi auto ditect disk driver jika ada jika tidak ada cek di } \\
\text { konfigurasi utama pasti ada prosedur mengenali hardisk. }\end{array}$ \\
\hline S6 & $\begin{array}{l}\text { Kabel Sata } \\
\text { Hardisk } \\
\text { Bermasalah }\end{array}$ & $\begin{array}{l}\text { Cek kabel sambungan hardis yang ada di dalam kesing jika ada } \\
\text { kabel hardis yang longar betolkan sampai benar benar terpasang } \\
\text { dengan sempurna }\end{array}$ \\
\hline S7 & $\begin{array}{l}\text { Seting } \\
\text { Jumper } \\
\text { Hardisk } \\
\text { Bermasalh }\end{array}$ & $\begin{array}{l}\text { Perhatikan seting jamper yang harus di pasang lihat pada buku } \\
\text { manual }\end{array}$ \\
\hline S8 & $\begin{array}{l}\text { Partition } \\
\text { Hardisk } \\
\text { Bermaslah }\end{array}$ & $\begin{array}{l}\text { Lakukan butting fdd atau CD/DVD pastikan bahwa di dalam disket } \\
\text { tersebut memiliki file perintas seperti format.com fdis,exe } \\
\text { Tekan tombol power sampai muncul prom A atau "A:|>“ } \\
\text { Jalankan program fdisk,exe dengan cara mengklikan Fdisk lalu } \\
\text { enter. } \\
\text { Jika hardis belum di partition sebelumnya maka file cread } \\
\text { dowspartition orligical dos driv lalu pilih cread primeri dos partition } \\
\text { jika anda ingin membuat hardis menjadi } 2 \text { driv makan jawab } \\
\text { pertanyaan tersebud dengan N. } \\
\text { masukan ukuran primeri dos partition dalam ukuran mb/presentase } \\
\text { buatlah partisi baru agar bisa digunakan untuk buting komputer } \\
\text { untuk mengaktifkannya pilik } 2 \text { untuk pada sub menu utama setaktif } \\
\text { partition. } \\
\text { Buatlah partisi ke2 pilih angka } 1 \text { pada menu utama dan pilih angka } \\
\text { ke2 pada sub menunya masukan ukuran yang di inginkan dan tekan } \\
\text { enter hingga muncul pesan extendit partition wascreated } \\
\text { Restar komputer }\end{array}$ \\
\hline S9 & $\begin{array}{l}\text { Setup Bios } \\
\text { Bermaslah }\end{array}$ & $\begin{array}{l}\text { Cek pada setup bios apakah terdeteksi cd/dvd room pilih opsi auto } \\
\text { detect jika ada jika tidak ada cek pada konfigurasi utama pasti ada } \\
\text { prosuder untuk mengenali cd/dvd room. }\end{array}$ \\
\hline S10 & $\begin{array}{l}\text { Driver } \\
\text { CD/DVD } \\
\text { Bermasalah }\end{array}$ & $\begin{array}{l}\text { Klik star padat taskbar windows kemudian pilih setting dan control } \\
\text { panel } \\
\text { Doubel klik icon system } \\
\text { Pilih tabulasi devic manager } \\
\text { Dari daftar devic yang muncul CD room } \\
\text { Pilih tombol rimove untuk menghapus deriver yang aktif } \\
\text { Lakukan booting ulang komputer agar windows mendeteksi } \\
\text { kembali secara otomatis CD/DVD room yang ada }\end{array}$ \\
\hline S11 & $\begin{array}{l}\text { Monitor/LCD } \\
\text { Mengalami } \\
\text { Kerusakan }\end{array}$ & $\begin{array}{l}\text { Cek kabel vga sudah masuk pada port vga yang ada pada kesing } \\
\text { komputer } \\
\text { Cek indikator pada monito apakah powernya berjalan normal apa } \\
\text { tidak } \\
\text { Coba buting ulanh }\end{array}$ \\
\hline
\end{tabular}




\begin{tabular}{|c|c|c|}
\hline Kode & $\begin{array}{c}\text { Jenis } \\
\text { Kerusakaan }\end{array}$ & Solusi Kerusakan \\
\hline S12 & $\begin{array}{l}\text { Gangguan } \\
\text { Pada VGA } \\
\text { Card }\end{array}$ & $\begin{array}{l}\text { Cek kabel VGA pada monitor dan kesing komputer masukan kabel } \\
\text { tersebut degan kaki kaki tersedia. } \\
\text { Cek konektor atau pin kabel VGA jika patah atau putus ganti dgan } \\
\text { yang baru } \\
\text { Istal ulang deriver vga card yang di pasang. } \\
\text { Download versi terbaru sofwer derex dari situs miscrosoft } \\
\text { Buka vga chard dari slotnya jika masih blank ganti vga card dengan } \\
\text { yang baru }\end{array}$ \\
\hline S13 & USB Rusak & $\begin{array}{l}\text { Matiakn komputer cabut perangkat usb dan kabel listrik yang } \\
\text { masuk ke monitor tunggu samapai 20-30 menit lalu hidupkan } \\
\text { seperti biasa jika tidak berhasih perhatikan port usb apa longar apa } \\
\text { tidak jika tidak terdeteksi juga gunakan devics meneger degan cara } \\
\text { klik star>run>Devngmt.msc klik enter. }\end{array}$ \\
\hline S14 & $\begin{array}{l}\text { Driver USB } \\
\text { mengalami } \\
\text { kerusakan }\end{array}$ & $\begin{array}{l}\text { Masuk ke CMD lalu ketikan „"set DEVMGR SHOW NONPRESENT } \\
\text { DEVICES=1“ dan enter } \\
\text { Klik menu view>show hidden devices } \\
\text { Menemukan devices usb dan unknow device, lalu unistal devics usb }\end{array}$ \\
\hline S15 & $\begin{array}{l}\text { Bios } \\
\text { mengalami } \\
\text { error }\end{array}$ & $\begin{array}{l}\text { Cabut bios pada komputer lalu flesh biosnya mengunakan effrom } \\
\text { dan ganti file bios degan yang bagus dalam laptop teknisi file bios } \\
\text { ada pada laptop teknisi komputer dan laptop dan WEB. }\end{array}$ \\
\hline
\end{tabular}

\subsection{Pemodelan Sistem Pakar}

Pemodelan proses sistem pakar merupakan tahap awal dalam merancang sebuah gambaran proses diagnosa kerusakan hardware komputer/laptop dimana akan membahas melalui diagramdiagram UML berikut [14].

\section{IMPLEMENTASI}

Tahapan penerapan dan mengoperasikan sistem pada keadaan yang sebenarnya dapat dikatakan sebagai bentuk implementasi, melalui tahapan ini sehingga nantinya akan diketahui apakah sistem yang telah dibangun benar-benar dapat berjalan sesuai dengan tujuan yang diharapkan.

Menu Utama
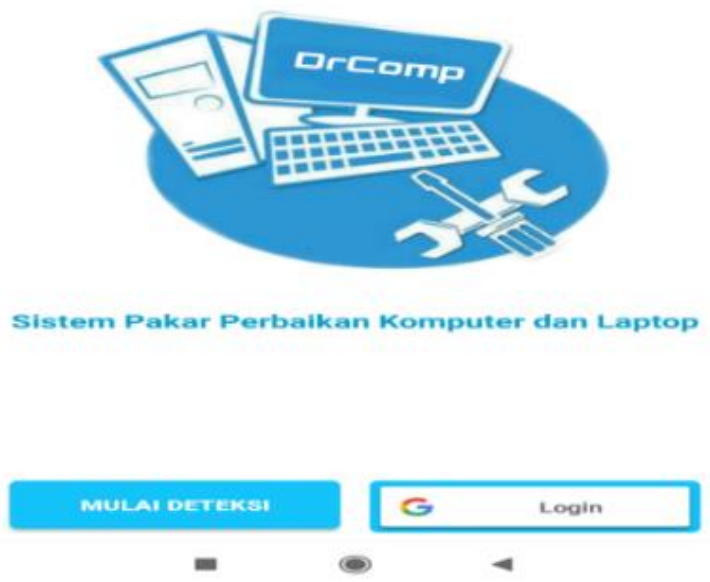

Gambar 4. Menu Utama

Menu utama ini biasa juga disebut dengan formhome bagian ini berisikan menu-menu yang memiliki link ke modul-modul program lainnya.Untuk penggunaannya hanya perlu memilih menumenu atau sub menu yang terdapat pada halaman ini. 


\section{Form Dashboard Admin}

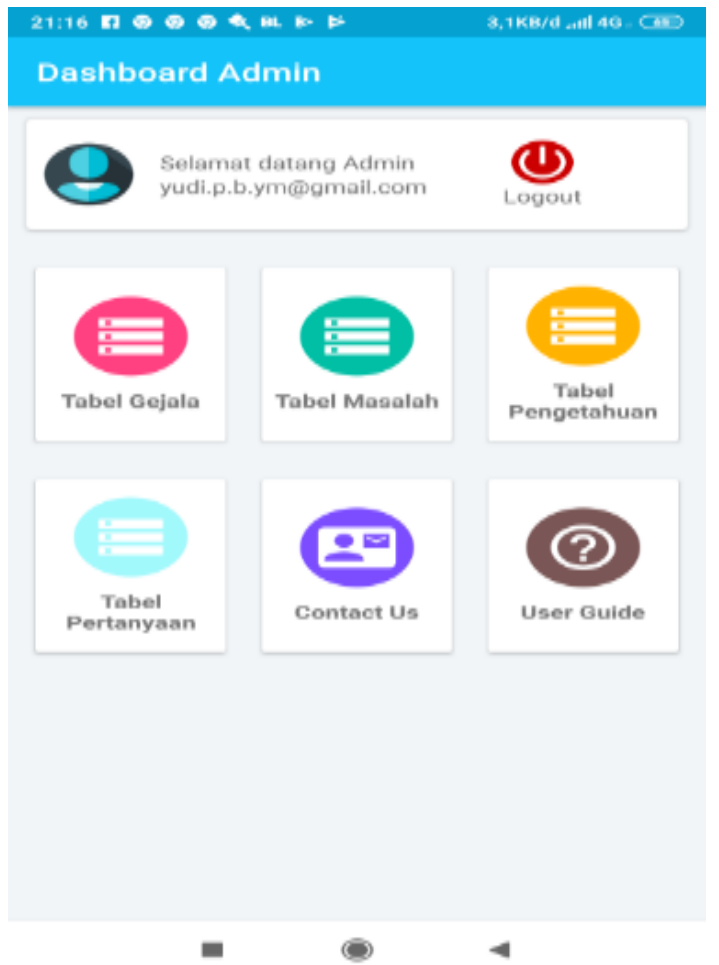

Gambar 5. Dashboard Admin

Tampilan gambar diatas menunjukkan halaman utama Admin untuk melakukan fugsinya sebagai administrator.

Form Deteksi Kerusakan

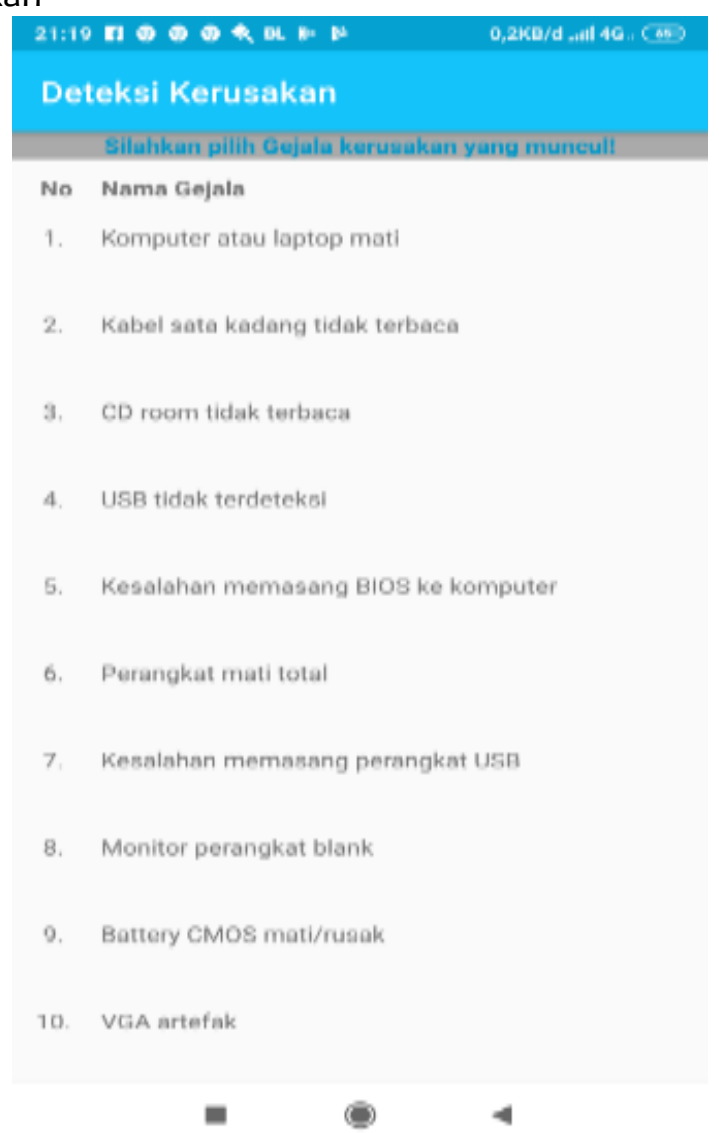

Gambar 6. Deteksi Kerusakan

Ridha, Forward Chaining Untuk Mendeteksi Kerusakan Komputer Dan Laptop Berbasis Android 
Tampilan gambar diatas menunjukkan halaman Form data deteksi kerusakan komputer dan laptop.

Form Tambah Data Masalah

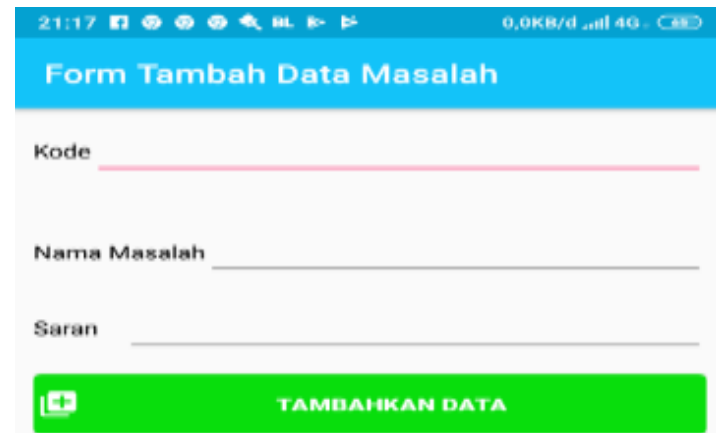

\section{Gambar 7. Form Tambah Data Masalah}

Tampilan form Tambah data masalah digunakan untuk menambahkan data Masalah yang berisikan kode kriteria dan keterangan. Pada form ini, untuk melakukan penambahan data Masalaha cukup dengan mengisikan kode Masalah dan keterangan, kemudian selanjutnya menekan tombol tambah data.

Tabel Gejala

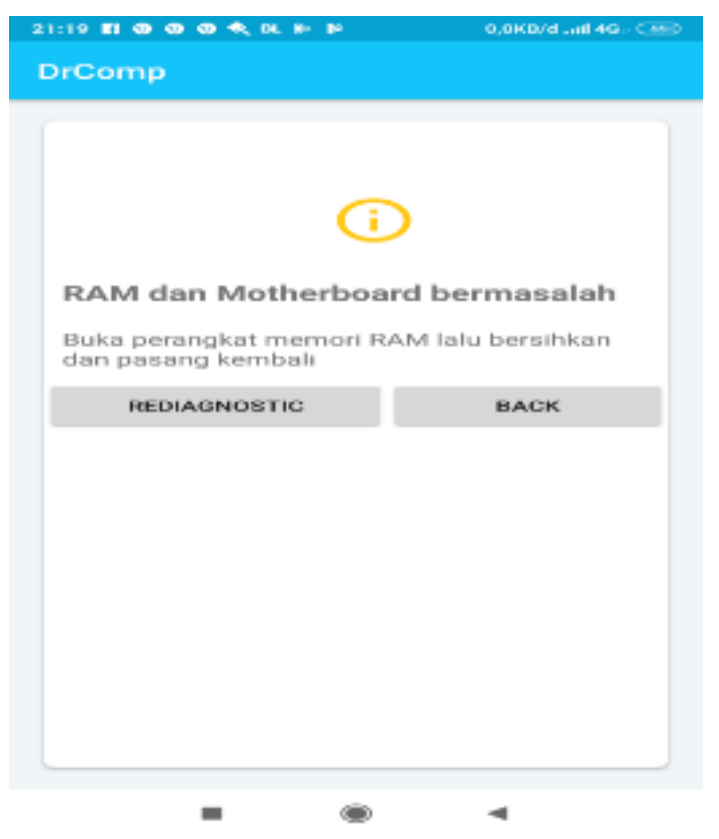

Gambar 8. Form Tabel Gejala

Tampilan gambar diatas menunjukkan halaman Tabel Gejala yang berisikan Gejala-gejala tentang kerusakan komputer dan Laptop.

Ridha, Forward Chaining Untuk Mendeteksi Kerusakan Komputer Dan Laptop Berbasis Android 
Form Pertanyaan

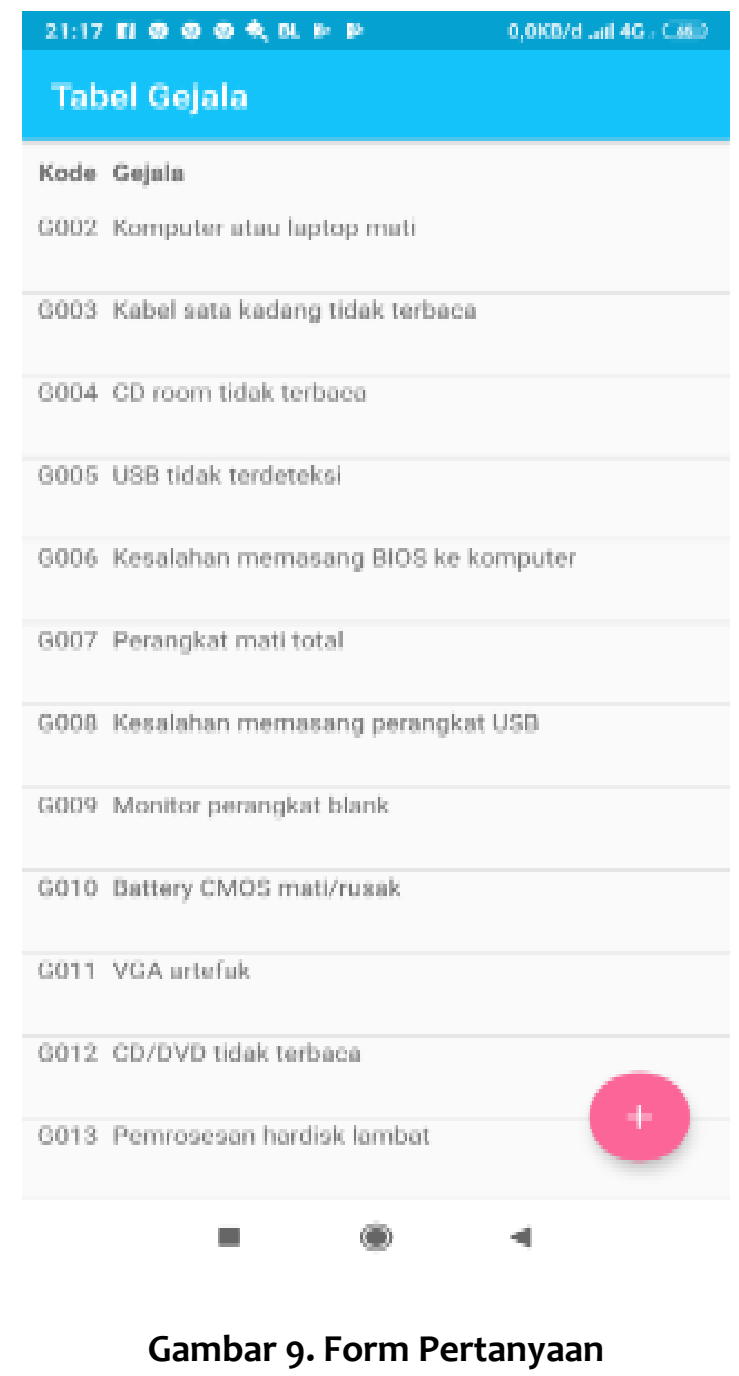

Tampilan gambar diatas menunjukkan halaman Form pertanyaan yang di gunakan oleh user untuk mendeteksi kerusakan komputer dan Laptop.

\section{KESIMPULAN}

Berdasarkan hasil pengembangan sistem yang telah penulis lakukan, penulis mencoba membuat suatu kesimpulan dan mengajukan saran-saran yang berhubungan dengan pembahasan yang telah dikemukakan sebelumnya, maka dapat disimpulkan beberapa hal sebagai berikut:

1. Aplikasi yang dibuat untuk memudahkan teknisi dalam kerusakan komputer yang dalam cara penyajiannya terdiri dari macam, jenis, cir-ciri kerusakan komputer.

2. Waktu yang dibutuhkan untuk mendiagnosa kerusakan pada komputer apabila menggunakan aplikasi yang dibutuhkan teknisi apabila mendiagnosa secara manual.

\section{REFERENSI}

[1] m. ilhami, "Pengenalan Google Firebase untuk Hybrid Moblie Apps Berbasis cardova," Jurnal IT CIDA vol. 3 no. 1, pp. 16-29, 2017.

[2] A. S. U. R. Sahil Barjtya, "A detailed study of Software Development Life Cycle (SDLC) Models," International Journal Of Engineering And Computer Science, vol. 6, no. 7, pp. 22097-22100, 2017. 
[3] E. P. Nency, "SISTEM PAKAR KERUSAKAN HARDWARE KOMPUTER," Jurnal Momentum, vol. 18, no. 2, pp. 53-59, 2016.

[4] A. Marlyaningrum, Aplikasi Sistem Pakar Diagnosis Pada Sistem Komputer, Bandung: Program Studi Sistem Informasi Universitas Widyatama, 2013.

[5] M. H. W. X. \&. W. J. Xu Tingting1, "Study on Design and Implementation of JAVA Programming," Higher Education Studies, vol. 5, no. 5, pp. 32-37, 2016.

[6] D. Android, "Retrieved From Developer Android," Developer Android, 1 January 2017. [Online]. Available: http://www.developerandroid.com/feature.html. [Accessed 30 December 2018].

[7] A. R. W. Khafiizh Hastuti, "Implementation of Firebase Realtime Database to track BRT Trans Semarang," Scientific Journal of Informatics, vol. 4, no. 2, pp. 95-103, 2017.

[8] R. Danu Murti Bimataka, "Identifikasi Kematangan Buah Naga Merah Menggunakan Metode Backprogation Berbasis Android," Universitas Teknologi Yogyakarta, vol. o, no. o, pp. o0, 2018.

[9] J. Andi, "PEMBANGUNAN APLIKASI CHILD TRACKER BERBASIS ASSISTED - GLOBAL POSITIONING SYSTEM (A-GPS) DENGAN PLATFORM ANDROID," Jurnal Ilmiah Komputer dan Informatika (KOMPUTA), vol. 1, no. 1, pp. 1-8, 2015.

[10] I. M. I. S. S. F. C. H. Maryuliana, "Sistem Informasi Angket Pengukuran Skala Kebutuhan MateriPembelajaran Tambahan Sebagai Pendukung Pengambilan Keputusan Di Sekolah Menengah Atas Menggunakan Skala Likert," Journal homepage, vol. 1, no. 2, pp. 1-12, 2016.

[11] Ismael, "RANCANG BANGUN SISTEM INFORMASI PENYALURAN SEMEN PADANG UNTUK DAERAH BENGKULU SELATAN DI CV. MUTIA BERSAUDARA," Jurnal EdikInformatika, vol. 3, no. 2, pp. 147-156, 2017.

[12] R. F. F. H. R. M.Sidi Mustaqbal1, "PENGUJIAN APLIKASI MENGGUNAKAN BLACK BOX TESTING BOUNDARY VALUE ANALYSIS," Jurnal IImiah Teknologi Informasi Terapan, vol. 1, no. 3, pp. 31-36, 2015.

[13] Furkonuddin, Buku Wajib (Teknisi Laptop Professional), Yogyakarta: LPK RJ-COMP Jogja, 2019 .

[14] Suendri, "Implementasi Diagram UML (Unified Modelling Language) Pada Perancangan Sistem Informasi Remunerasi Dosen Dengan Database Oracle," Jurnal Ilmu Komputer dan Informatika, vol. 3, no. 1, pp. 1-9, 2018.

[15] W. L. S. Bagus Prasetyo, "SISTEM PENDUKUNG KEPUTUSAN PEMILIHAN PAKET INTERNET OPERATOR TELEKOMUNIKASI DENGAN METODE AHP," Jurnal TIKomSiN, Vols. -, no. -, pp. 7-12, -. 